\title{
Practices and Prospects of Learner Autonomy: Teachers' Perceptions
}

\author{
AbdulRahman Al Asmari ${ }^{1,2}$ \\ ${ }^{1}$ Preparatory Year Deanship, Taif University, At-Taif, Kingdom of Saudi Arabia \\ ${ }^{2}$ Director, English Language Centre, Taif University, At-Taif, Kingdom of Saudi Arabia \\ Correspondence: Dr. AbdulRahman Al Asmari, Dean PYP/ Director, English Language Centre, Taif University, \\ PO Box 888, At-Taif, Zip Code 21974, Saudi Arabia. Tel: 966-557-344-666. E-mail: abdulasmari@gmail.com
}

Received: December 31, 2012 Accepted: January 12, 2013 Online Published: February 1, 2013

doi:10.5539/elt.v6n3p1 URL: http://dx.doi.org/10.5539/elt.v6n3p1

\begin{abstract}
Language learning process works through the learners' own reflection on how they learn and it makes learners active in the sense that they learn to analyze their learning strategies. So they start making decisions, e.g., whether to improve them or not, and in which way. Generally, this trait is missing in traditional language teaching process and students are not expected to reflect upon their own learning, analyzing and evaluating their learning experience. Retrospective tasks, such as interviews, group discussion and structured questionnaires encourage learners to reflect upon learning and these retrospective activities may help learners to take responsibility for their language learning processes as autonomous learners and thus making a motivated learner. The role of the teacher is central to the development of learner autonomy (Hurd, Beaven, \& Ortega, 2001; Benson, 2009). A teacher is required to create a classroom learning environment that is supportive of learner autonomy. This may involve the teacher first addressing learners' past learning experiences, then slowly raising their awareness to the benefits of increased independence in their learning. Dickinson (1993) adds that learner training should aim to help learners develop the ability to take more responsibility for their own learning. To do this, a survey was conducted at Taif University English Language Centre (KSA) to collect the opinion of teachers regarding the practices and prospects of learner autonomy in their classrooms. The sample consisted of 60 teachers from different countries teaching English to Arab students at University level. The study focused on the teachers' notion of learner autonomy, its practices and prospects in Saudi Arabian context. Findings stress that it is important to provide learner training together with the studies and make it an integral part of the teaching process so as to help learners become autonomous.
\end{abstract}

Keywords: learner autonomy, teaching strategies, English language teaching

\section{Introduction}

In a traditional classroom, teacher is the authority as a source of knowledge, deciding on what to learn and how to learn. Also he designs classroom activities, motivate the students and provide authoritative feedback on students' performance in the classroom. Tudor (1993) suggests that the main role of the teacher in the traditional modes of teaching is the supplier of knowledge. On the other hand, teachers promoting learner autonomy perform their role differently. Their role is more of a facilitator and counselor as they help students to take the responsibility by setting their own goals, planning practice opportunities, or assessing their progress. It means that learner autonomy depends on teacher autonomy as both are fully involved in achieving the optimum effectiveness of language teaching and learning. Teachers guide the students to accept responsibility for their own learning, guide them to be reflectively engaged in planning, monitoring and evaluating their learning.

There are many strategies which may help the teachers who want to promote opportunities for learners to become more autonomous learners. It is imperative from the very beginning that the roles of the teachers and learners should be identified and introduced to the learners. A teacher should provide the students appropriate tools and opportunities for practice in the language classroom. Presupposing that the teachers are willing to change and shift their role from teaching knowledge-based to supervising students learning-based, a teacher's responsibilities is to facilitate the change. The role of a teacher is very important in this process as 'the ability to behave autonomously for students is dependent upon their teacher creating a classroom culture where autonomy is accepted" (Barfield et al., 2001, p. 3).

In Saudi Arabia, there are many factors affecting the teaching-learning process. The students face problems at 
university because they don't study English in early stages and don't use English as medium of instruction except in certain higher education courses. Also, environment and family background play vital role in learning English. Poor educational background of parents and income add to such problems. That's why most of the students bear extrinsic motivation and learn English to get good jobs (Javid, Al Asmari, \& Farooq, 2012). Most of the English language teachers at school levels are usually Arabs and they communicate with their students in their native language. The teachers usually give instructions in writing instead of directly conveying them to their students. In assigning topics to students, the teachers demand that they should be completed either inside their classroom or at home. As part of the teaching method in most Arab schools, the teachers do not really necessitate their students to revise or modify their works. The students are usually left alone in revising or making drafts of their own works without any guidelines (Al-Hazmi \& Scholfield, 2007). This confirms most observations of researchers that teachers usually count on the personal interests of their students to learn. In some cases this practice might work as this could inculcate in the minds of the students the value of independence or self-reliance, but in most cases it would hamper the academic development of the students.

Therefore, it was imperative to understand teachers' beliefs about learner autonomy which is reflected through practices and strategies to promote learner autonomy in their classrooms. The present research focuses on finding on practices and prospects of teachers teaching English language to undergraduate Arab students.

\section{Literature Review}

Various approaches, methods and techniques have been introduced in the field of English language teaching (ELT) with the passage of time all over the world to improve the English language teaching/learning situation within and outside the classroom. The focus shifted from teacher-centered to learner-centered approach and communicative approach was introduced to provide opportunities to the learners to use the language in real-life contexts. Jacobs and Farrell (2003) suggest that the communicative language teaching (CLT) paradigm shift led to eight major changes in approaches to language teaching/learning and the most important change is the learner autonomy. The goal is to enable students to become autonomous individuals capable of coping with the demands of the world. The concept of learner autonomy got attention of ESL teachers and researchers in 1980s when Henri Holec defined the term as the ability to take charge of one's own learning (Benson, 2006), and much attention was devoted to this concept for creating a better understanding between teachers and students. Some commonly used definitions of learner autonomy are:

- '...a capacity and willingness to act independently and in cooperation with others, as a social, responsible person' (Dam, Eriksson, Little, Miliander, \& Trebbi, 1990, p. 102)

- '... an attitude towards learning in which the learner is prepared to take, or does take, responsibility for his own learning' (Dickinson, 1994, p. 167)

- '... a capacity for detachment, critical reflection, decision making and independent action' (Little, 1991, p. 4)

In a study, Chan (2001) reported that the learners identified the following characteristic qualities of autonomous learners: highly motivated, goal oriented, well organized, hard working, initiative, enthusiastic about learning, flexible, active, willing to ask questions, and making use of every opportunities to improve their learning. Nunan (1997) found encouraging learners to move towards autonomy is best done inside the language classroom.

Learner autonomy can be supported by teachers' minimizing the evaluative pressure and any sense of coercion in the classroom, as well as by maximizing students' perceptions of having a voice and choice in the academic activities. Researchers suggest that autonomy-supportive teaching practices are associated with positive outcomes in the classroom. For example, Chirkov and Ryan (2001) studied Russian and US high-school students and found that students' perceptions of both teacher and parent autonomy support were associated with greater internalization of academic motivation. Another important aspect of autonomy support that has been shown to facilitate internalization is that teachers provide students with a meaningful rationale for why a learning activity is useful.

Recent developments in the field of technology have modified our learning styles by allowing us to obtain a great amount of information. This phenomenon has had a significant impact on language learning in different countries. Teachers need to consider integrating students' preferences into teaching to promote students' learning and motivation and to help students appreciate social interaction through the use of technology in language learning. The integration of computers into language teaching and learning has been widely accepted by many educators and researchers (Warschauer \& Whittaker, 1997; Warschauer \& Healey, 1998; White \& Weight, 2000). Many language teachers deploy technology to provide students with opportunities to continue learning outside the classroom because web-based learning allows learners to work at their own pace and to have the freedom to 
choose their own materials. Internet provides students with authentic and global environments and various interesting tools to achieve learner autonomy and offers them an opportunity to learn, practice and communicate with others in the target language outside the classroom (Pinkman, 2005). De Vries and Kohlberg (1987, p. 380) explain an autonomous teacher in these words:

The autonomous constructivist teacher knows not only what to do, but why. She has a solid network of convictions that are both practical and theoretical. The autonomous teacher can think about how children are thinking and at the same time think about how to intervene to promote the constructive culture. Autonomous teachers do not just accept uncritically what curriculum specialists give them. They think about whether they agree with what is suggested. They take responsibility for the education they are offering children.

\subsection{Previous Studies on Teachers' Perceptions of Autonomy}

Various studies have been conducted on teachers' beliefs regarding learner autonomy. Camilleri (1999) collected data from 328 teachers from six European contexts (Malta, The Netherlands, Belorussia, Poland, Estonia and Slovenia). According to the teachers, students should be involved in decisions about a range of learning activities, such as establishing the objectives of a course or selecting course content. Camilleri (2007) replicated this study with a group of 48 respondents made up of student, teachers and practicing teachers of modern languages in Malta. She found positive views expressed by teachers as well as in the specific aspects of autonomy they were more and less supportive of. Balçıkanlı (2010) examined the views of 112 student teachers of English in Turkey. The results suggested that the student teachers were positive about involving students in decisions about a wide range of classroom activities. Al-Shaqsi (2009) conducted his research with 120 teachers of English in state schools in Oman. The teachers assessed their learners positively on all of the indicators of learner autonomy.

Borg and Al-Busaidi (2012) discuss that despite a substantial volume of research over 30 years, research on learner autonomy has paid limited attention to the sense teachers make, theoretically and in practice, of this concept. That's why, we lack a basis for understanding how teachers interpret the notion of learner autonomy and, where necessary, for encouraging them to make it a more central aspect of their work. They view it as a set of skills or abilities that learners need to master in order to learn independently. The teachers have diverging views about the extent to which their learners are autonomous; such views are underpinned by different conceptions of what counted as evidence of autonomy in their learners. Teachers often associate autonomy with opportunities for independent learning, irrespective of whether learners engaged with these. Also they feel it is desirable to involve learners in a range of decisions about their learning and teachers' beliefs about the feasibility of doing so, particularly in relation to objectives, assessment and materials. Such a gap between theory and practice confirms insights from other studies of EFL teachers' beliefs about learner autonomy. The majority of the teachers believed that they promoted learner autonomy in their teaching. Their descriptions of how they did so highlighted a range of pedagogical strategies from advocacy and awareness-raising to independent out of class language learning activities (Bullock, 2011; Yoshiyuki, 2011). These points are parallel with the findings of Reinders and Lazaro (2011), where teachers felt that learners did not understand the importance of developing autonomy, lacked the skills to learn independently, and were not accustomed to being asked to take responsibility for their learning.

\subsection{Context of the Present Study}

Keeping in view the teaching and learning English in the Saudi context, the students speak their native language at home and during their interaction with their friends, peers, classmates and even teachers, so there are obviously less chances to learning English through day-to-day interaction. Also the students are usually left alone in revising or making draft of their own works without any guidelines (Al-Hazmi \& Scholfield, 2007). Khan (2011) identifies the following reasons for poor quality of the learners: a) school graduates have lack of information regarding the university or college they enrolled in; b) there is deficiency in the English language curricula offered by some schools and universities; c) dreadful teaching methodology at school level. Thanasoulas (2000) discusses that teachers play a crucial role in creating environments to facilitate and motivate learners to take responsibility for their learning, develop good learning habits, become independent learners and be better able to control learning environments to practice language skills and communicate with others both in and out of the classroom and even after the course.

Taif University English Language Centre (TUELC) provides a congenial English language learning environment to the students enrolled in various programs of the University. The most recent syllabus introduced at the TUELC has set out to take up the task of challenging the traditional approach. It is obligatory that instructions should be designed to be appropriate for students' different levels and students should be taught according to their aptitude and interest. Foreign/second-language researchers have investigated a variety of language learning 
tasks/skills whereas much additional research remains to be done with language learning techniques, especially focusing on learner autonomy which can help students enhance their language skills.

\section{Research Questions}

i. How do the university teachers perceive learner autonomy in an ELT classroom?

ii. What practices do the university teachers offer to create an autonomous learning environment?

iii. What strategies do the university teachers think to be adopted to improve learner autonomy?

iv. What challenges do the university teachers face in helping their learners become more autonomous?

v. Is there any difference of opinion among male and female university teachers regarding learning autonomy?

\section{Research Design}

The present research was a survey-based study on current practices and prospects of learner autonomy in English language teaching at university level. Data were gathered through a questionnaire having 30 items on a five-point scale of agreement. It had three sections: current situation, practices and prospects of learner autonomy. The survey items aim to find out student-teachers' ideas as to what extent students should be involved in decision making processes concerning the general aspects of their own learning as mentioned by Nunan (1996). In order to explore teachers' beliefs about learner autonomy, a questionnaire was designed containing three sections; the first section explored the current situation of practicing learner autonomy and students' involvement in decision making process, the second section focused on teaching practices through which teachers want to inculcate learner autonomy and problems they face, and the third section explored the teachers' prospects of promoting learner autonomy. The questionnaire was administered to a group of 60 teachers, both male and female, teaching English at TUELC. The questionnaire was facilitated through the administration so the researcher got back all the questionnaires. A statistical analysis was carried out for discussion and suggestion for developing learner autonomy at university level especially for English language learners.

\section{Results}

The data collected from the teachers through questionnaires were tabulated and analyzed through mean. The questionnaires consisted of three parts and the responses have been analyzed accordingly. The purpose was to investigate the present status of learner autonomy, teaching practices and strategies for developing learning autonomy in an English language classroom.

\subsection{Learner Autonomy - Current Situation}

The first section of the questionnaire focused on the current situation of learner autonomy in an ELT classroom. The data reflects a discouraging situation as means of all the statements is below 4 (maximum being 5). However, the most favourite statements of the teachers included 'students access their performance in tests and compare it with other students (3.63), students feel very concerned to perform well and correctly in the classroom (3.58) and student think about its relationship to the rules they have learned while learning a new grammar rule (3.50)'. On the other hand, the least favourite statements were 'students try to discover knowledge in English on their own rather than waiting for knowledge from the teacher (2.75), students set up their own learning goals (2.87) and students tell the teacher what they would like to learn $(2.97)^{\prime}$. There is little variation in responses from male and female teachers.

\subsection{Inculcating Learner Autonomy through Teaching Strategies}

The second section of the questionnaire focused on teaching strategies which inculcate learner autonomy in an EFL classroom at the university level. Voller (1997) identifies three roles for teachers willing to work on an autonomous pedagogy: the teacher as facilitator, the teacher as counselor, and the teacher as resource. The data reveals the teaching strategies through which teachers try to inculcate learner autonomy. The most favored statements were 'teaching communicative skills (4.37), group discussions (4.30) and prefer learner-centered approach (4.27). On the other hand, the least favored statements included 'poor teaching facilities (3.50), poor learner's quality (3.62) and student's poor responsibility in learning (3.65)'. Both male and female teachers have almost the same responses.

\subsection{Learner Autonomy - Futuristic}

Autonomy demands redefinition of teacher's role aiming at the autonomous outcomes of the student. It calls for a new positioning in classroom interaction between students and teachers so that they can proceed together, creating multiple opportunities for learning. The data reveals teachers' futuristic approach towards introducing learner autonomy in an EFL classroom. They favored the statements including 'continuous professional 
development (4.50), reflection on teaching-learning process (4.37), focus on learner training (4.15)'. On the other hand, the statements included 'receive necessary theoretical support from the university (3.35), learner should be as autonomous as possible (3.72) and learner training fosters reflective attitude (3.82)' reported the least means.

\section{Discussion}

\subsection{Learner Autonomy - Current Situation}

The current status of learning autonomy, as perceived by the teachers, is not encouraging as all the statements regarding students' involvement in decision making is below 4 (average being 5). However, the students assess their performance, compare with their classmates and feel concerned to perform well in the classroom. This reflects that the students were interested in their performance and were concerned more about their grades. On the other hand, their motivational level and participation in autonomous learning is not so encouraging. It suggests that the teachers had different expectations of what autonomous learners were able to do. Bearing in mind that, the students are not encouraged to learn English at school level in Saudi Arabia, it also suggests that most of the students come without having sufficient background of independent learning. Hence, the teachers are assumed to start with the very basic ideas of self-learning, independent learning and learner autonomy at the university level. Several studies have suggested that students should be considered equal partners and given an opportunity to determine the time, place and pace of the course (Little, 1991; Dam, 1995; Nunan, 1997; Benson, 2001). It will provide students with a sense of self-confidence because they are given room to decide on these issues, which will guide them to increase their sense of responsibility for the learning process (Balçıkanl1, 2010).

However, many teachers may encounter difficulty in involving the students in decision making as the students may have different expectations and learning styles. They are reluctant to bring more learner autonomy into the classroom because they feel that since their students come from cultures which depend heavily on the authority of both the teachers and institutions (e.g., Saudi Arabia), they will feel uncomfortable with learner autonomy initiatives. Also, teachers could be afraid of handing over some responsibility to their learners for fear of losing control, especially if they have had control of the classroom for most of their teaching life (Lacey, 2007). In addition, some teachers have a strict curriculum to follow and deadlines to meet which make the development of learner autonomy all the more difficult (Smith, 2003).

This situation will be more challenging to accommodate the learners' needs and expectations. However, it will lead to learning centered environment in which learners are able to be consciously involved in their own learning. In such an environment, teachers and learners are expected to become a learning community and the target language is one of the principal tools with which the collaborative process is shaped (Little \& Dam, 1998). The target language is used not just in communication, but also as a channel for learning, and a tool for reflection (Little, Ridley, \& Ushioda, 2003). The teaching is not steered by the textbook, but the needs and experiences of the learners. To manage learners' learning process the teacher negotiates with them the course content and methodology. At the same time, the learners are informed about the learning process and discuss it. The learner forms his own conclusions about learning and is respected for his individual points of view (Camilleri, 1999). This process starts at the beginning of each year and continues throughout.

\subsection{Teaching Strategies}

The data reveals that teachers favored 'teaching communicative skills, group discussions and learner centered approach but challenges they had included poor teaching facilities, learner's quality and learner's responsibility in learning. Amongst other reasons, Khan (2011) identifies the following reasons for poor quality of the learners: a) problems with proper language environments; b) lack of personal impetus on the part of the students. Motivation plays an important part in improving and developing the learners' communicative ability. From another perspective, it is extrinsic motivation which compels students to learn English for a better job (Javid et al., 2012). The present study findings show that there are some learners who are intrinsically motivated, but they are in a minority.

Borg and Al-Busaidi (2012) suggest that there is a connection between learners' proficiency in English and their ability to develop as autonomous learners; however, promoting autonomy is easier with beginning language learners than with more proficient learners. For this reason, students' interests need to be utilized and the subject has to be appropriate for their abilities. It means that the teacher has to allow students freedom of choice in classroom activities. One of the important characteristics of the autonomous classroom is pair and group work as a means to develop learner autonomy. The fact is that learners become less dependent on the teacher by learning to collaborate with their peers. In this regard, Jacobs and Farrell (2001) argue that group activities play a large part in this because learners acquire a lot of learning strategies when collaborating with, and receiving support 
from their peers and not just the teacher. If students are actively involved in determining the classroom and group norms, they naturally tend to abide by these rules without teachers' having to exercise their authority (Dörnyei, 2001; Benson, 2001). Therefore, students need to be involved in formulating classroom rules in order to feel a part of the community in which learning takes place and it gives them encouragement for taking greater responsibility for their own learning. Students may feel certain difficulties while working in a group as it demands a lot of cooperation from all the members of the group. This can be supported by Seeman and Tavarese's findings (2000) which reveal that learners do not initiate dialogue in the target language and it can become problematic maintaining motivation in a mixed-ability environment. Therefore, the most important aspect of implementing learner autonomy in the classroom is the planning. Planning ahead and gathering relevant material to different learning tasks beforehand could save time for teachers (Little, Ridley, \& Ushioda, 2002).

As a facilitator, a teacher can promote learner autonomy through the curriculum by integrating the principles of autonomy into the learning goals, the learning process, tasks, learner strategies and reflection on learning. In classroom, students are encouraged to be interdependent and to work collaboratively. In developing learner autonomy, the teacher-student relationship is crucial. The trust and cooperation between the teacher and the students makes the students feel comfortable and secure in the classroom. Only then can the students have the confidence to adventure in language learning (Voller, 1997). As such, the teachers need to redirect their own beliefs of learner autonomy; otherwise they could, intentionally or unintentionally, constrain learner autonomy in the classroom 'leading to a lack of authenticity in learning which can disconnect it from real life' (Lamb, 2008, p. 273).

In a learner autonomous classroom, a teacher becomes more of a manager, a resource person and a counselor (Camilleri, 1997). A teachers as a manager needs to be skilful in managing a class where learners actively participate in decision-making, as a resource persons helps learners to develop an awareness of their learning styles and learning strategies, and as a counselor offers advice to help them manage learning difficulties. Based on that, promoting teachers' perceptions of learner autonomy can be a challenging task and teachers need preparation and support. Preparation can be incorporated in in-service teacher education programs where teachers can share practical ideas of introducing learner autonomy in the classroom.

In terms of support, it needs to be provided at an institutional level to allow greater flexibility in teaching and to offer an avenue where teachers can promote learner autonomy in teaching and learning. A teacher intending to promote learner autonomy should introduce various learning strategies aiming at providing the learners ample opportunities of working in an independent learning environment. To do this, Cotterall's five principles for language course design can be adapted to foster learner autonomy and support the transfer of responsibility for decision-making from teacher to learner. These steps are:

1) The course reflects learners' goals in its language, tasks, and strategies. 2) Course tasks are explicitly linked to a simplified model of the language learning process. 3) Course tasks either replicate real-world communicative tasks or provide rehearsal for such tasks. 4) The course incorporates discussion and practice with strategies known to facilitate task performance. 5) The course promotes reflection on learning (1999, $\mathrm{p}$. 111-112).

\subsection{Learner Autonomy - Futuristic}

In the last part of the questionnaire, data analysis results displayed the teachers' suggestions on futuristic steps for improving learner autonomy which included 'continuous professional development, reflection on teaching-learning process and focus on learner training'. Various studies (e.g., Little, 1995; Smith, 2000) confirmed that teachers who themselves are not autonomous language learners may have a negative influence on the development of autonomy in their students. Based on the present study findings, it is imperative to arrange autonomy-oriented training for the language teachers. It is assumed that a teacher who is trained on autonomous skills will be able to take a positive stance towards the development of learner autonomy in their own teaching and have a potential to assist their students to take charge of their own learning following the models of their teachers. This goes in line with Little (1995) who contends that learner autonomy depends on teacher autonomy in two senses: it is unreasonable to expect teachers to foster the growth of autonomy in their learners if they themselves do not know what it is to be an autonomous learner. In determining the initiatives they take in their classrooms, teachers must be able to apply to their teaching those same reflective and self-managing processes that they apply to their learning (p. 175). In autonomous learning, the exact nature of teachers' role varies according to contexts and personalities involved. Generally, a teacher in such learning is a facilitator, an organizer, a resource person providing learners with feedback and encouragement, and a creator of learning 
atmosphere and space. In other words, a teacher works as a guide, a co-operative and an initiator rather than an authority.

The present study findings revealed that the teachers encounter various hurdles in introducing learner autonomy in their classrooms which were reflected through their responses in the questionnaire, including 'receive necessary theoretical support from the university (3.35), learner should be as autonomous as possible (3.72) and learner training fosters reflective attitude (3.82)'. Shifting focus from teaching to learning is not simple, easy or a change that happens overnight. It requires a different way of thinking about classroom dynamics and the roles of teachers, as well as learners. It requires a lot of planning which should be undertaken in association with learners, fellow teachers, administration and parents. For successful implementation of learner autonomy, it is important that all those concerned are aware of the rationale behind the different working, learning and assessment methods.

\section{Conclusion}

This study focused on the teachers' perspectives on learner autonomy in English language learning at the university level. Through a survey questionnaire consisting of three sections based on the principles of learner autonomy, the teachers (males and females) reported on the present situation of learner autonomy and understanding of the concepts from learner point of view. The current situation is a challenging one for the teachers but it may lead towards a learning centered environment if the learners are involved in their own learning. A teacher should initiate the learning process by sharing the course objectives, contents and methodology in the beginning of each academic session. In the next section, the participants reported on the practices through which teachers try to inculcate the concept and final section focused on how to improve learner autonomy in Saudi Arabian context. On the whole, the teachers, both males and females, agreed to the idea that students should be involved in the decision making process concerning the language learning. The results indicated a strong preference for a more autonomous learning process, but the teachers themselves lacked proper training and expertise in this area. Findings confirmed the assumption that the autonomous learner takes a proactive role in the learning process, generating ideas and availing himself/herself of learning opportunities, rather than simply reacting to various stimuli of the teacher. Also, the teachers expect learners to work independently and take responsibility of their learning.

Learners are, therefore, challenged to manage their language studies in a variety of ways like reflecting on their own thinking process, evaluate their performance and make important decisions regarding their studies. Based on the present study findings, introducing learner autonomy necessitate a redefinition of the teachers' role can be bound by an institutional change involving the teachers as discussed in the third section of the survey. An autonomous teacher should be aware of his own personal influence on the learning process, understand pedagogy and skills in management. The teacher is no longer the knowledge supplier but also a manager, resource person and counselor. Teachers' concerns regarding learner autonomy need to be addressed before autonomous learning initiatives are initiated in the classroom. The teacher should involve learners in their own learning, giving them ownership of learning objectives and the learning process and getting the learners to reflect about learning and about the target language.

\section{References}

Al-Hazmi, S. H., \& Scholfield, P. (2007). Enforced revision with checklist and gaze feedback in EFL writing: The examples of Saudi university students. SJKFU, 8(2), 237-258.

Al-Shaqsi, T. S. (2009). Teachers' beliefs about learner autonomy. In S. Borg (Ed.), Researching English language teaching and teacher development in Oman (pp. 157-165). Muscat: Ministry of Education, Oman.

Balçıkanlı, C. (2010). Learner autonomy in language learning: Student teachers' beliefs. Australian Journal of Teacher Education, 35(1), 90-103.

Barfield, A., Ashwell, T., Carroll, M., Collins, K., Cowie, N., Critchley, M., Head, E., Nix, M., Obermeier, A., \& Robertson, M. C. (2001). Exploring and defining teacher autonomy: A collaborative discussion. In A. S. Mackenzie, \& E. McCafferty (Eds.), Developing Autonomy, Proceedings of the College and University Educators' 2001 Conference, Shizuoka, Japan (pp. 217-22). Tokyo: The Japan Association for Language Teaching. Retrieved 12-10-2012 from http:/www.encounters.jp/mike/professional/publications/tchauto.html

Barillaro, F. (2011). Teacher perspectives of learner autonomy in language learning MA dissertation. TESOL Centre. Sheffield Hallam University.

Benson, P. (2001). Teaching and researching autonomy in language learning. Harlow: Longman. 
Benson, P. (2006). Autonomy in language teaching and learning. Language Teaching, 40(1), 21-40. http://dx.doi.org/10.1017/S0261444806003958

Benson, P. (2009). Making sense of autonomy in language learning. In R. Pemberton, S. Toogood, \& A. Barfield (Eds.), Maintaining control: Autonomy and language learning (pp. 13-26). Hong Kong: Hong Kong University Press. http://dx.doi.org/10.5790/hongkong/9789622099234.003.0002

Borg, S., \& Al-Busaidi, S. (2012). Learner Autonomy: English Language Teachers' Beliefs and Practices. London: British Council.

Bullock, D. (2011). Learner self-assessment: An investigation into teachers' beliefs. ELT Journal, 62(2), 114-125. http://dx.doi.org/10.1093/elt/ccq041

Camilleri, G. A. (2007). Pedagogy for autonomy, teachers' attitudes and institutional change: A case study. In M. J. Raya, \& L. Sercu (Eds.), Challenges in teacher development: Learner autonomy and intercultural competence (pp. 81-102). Frankurt: Peter Lang.

Camilleri, G. (1997). Learner autonomy: The teachers' views. Retrieved 24-11-2012 from www.ecml.at/documents/pubCamilleriG_E.pdf

Camilleri, G. (Ed.). (1999). Learner Autonomy - The Teachers' Views. Strassbourg: Council of Europe Publishing.

Chan, V. (2001). Readiness for learner autonomy: What do our learners tell us? Teaching in Higher Education, 6(4), 505-519. http://dx.doi.org/10.1080/13562510120078045

Chirkov, V. I., \& Ryan, R. M. (2001). Parent and teacher autonomy-support in Russian and U.S. adolescents: Common effects on well-being and academic motivation. Journal of Cross-Cultural Psychology, 32, 618-35.

Cotterall, S. (1999). Key variables in language learning: what do learners believe about them?. System, 27(4), 493-513. http://dx.doi.org/10.1016/S0346-251X(99)00047-0

Dam, L. (1995). From theory to classroom practice. Dublin: Authentik.

Dam, L., Eriksson, R., Little, D., Miliander, J., \& Trebbi, T. (1990). Towards a definition of autonomy. In T. Trebbi (Ed.), Third Nordic workshop on developing autonomous learning in the FL classroom (pp. 102-103). Bergen: University of Bergen.

DeVries, R., \& Kohlberg, L. (1987). Programs of early education. New York: Longman.

Dickinson, L. (1993). Talking shop: Aspects of autonomous learning, An interview with Leslie Dickinson. ELT Journal, 47(1), 330-341.

Dörnyei, Z. (2001). Motivational strategies in the language classroom. Cambridge: Cambridge University Press. http://dx.doi.org/10.1017/CBO9780511667343

Fenner, A. B., \& Newby, D. (Eds.). (2000). Approaches to Materials Design in European Textbooks: Implementing Principles of Authenticity, Learner Autonomy and Cultural Awareness. Graz/Strasbourg: European Centre for Modern Languages/Council of Europe Press.

Hurd, S., Beaven, T., \& Ortega, A. (2001). Developing autonomy in a distance language learning context: Issues and dilemmas for course writers. System, 29(3), 341-355.

Jacobs, G., \& Farrell, T. (2003). Understanding and Implementing the CLT Paradigm. RELC Journal, 41(1), 5-30.

Jacobs, G. M., \& Farrell, T. S. (2001). Paradigm Shift: Understanding and Implementing Change in Second Language Education. Retrieved 01 01, 2011, from TESL - EJ: Teaching English as a second or foreign language. Retrieved 09-9-2012 from http://teslej. org/ej17/a1.html

Javid, C. Z., Al Asmari, A. R., \& Farooq, U. (2012). Saudi Undergraduates' Motivational Orientations towards English Language Learning along Gender and University Major Lines: A Comparative Study. European Journal of Social Sciences, 27(2), 283-300. Retrieved 22-9-2012 from http://www.europeanjournalofsocialsciences.com

Khan, I.A. (2011). Learning difficulties in English: Diagnosis and pedagogy in Saudi Arabia. Educational Research, 2(7), 1248-1257.

Lacey, F. (2007). Autonomy, never, never, never! Independence, 42, 4-8.

Lamb, T. E., \& Reinders, H. (Eds.). (2008). Learner and teacher autonomy: Concepts, realities, and responses. 
Amsterdam: John Benjamins.

Little, D. (1991). Learner autonomy: Definitions, issues and problems. Dublin: Authentik.

Little, D. (1995). Learning as dialogue: The dependence of learner autonomy on teacher autonomy. System, 23(2), 175-182. http://dx.doi.org/10.1016/0346-251X(95)00006-6

Little, D., Dam, L., \& Timmer, J. (Eds.). (1998). Focus on Learning Rather than Teaching: Why and How? Papers from the International Association of Teachers of English as a Foreign Language (IATEFL) Conference (Krakow, Poland, May 14-16, 1998) (pp. 38-56). Dublin: Centre for Language and Communication Studies.

Little, D., Ridley, J., \& Ushioda, E. (Eds.). (2002). Towards greater learner autonomy in the foreign language classroom. Dublin: Authentik Language Learning Resources Ltd.

Little, D., Ridley, J., \& Ushioda, E. (Eds.). (2003). Learner autonomy in the foreign language classroom: Teacher, learner, curriculum and assessment. Dublin: Authentik.

Nunan, D. (1996). Towards autonomous learning: Some theoretical, empirical and practical issues. In R. Pemberton, et al. (Eds.), Taking control: Autonomy in language learning (pp. 13-26). Hong Kong: Hong Kong University Press.

Nunan, D. (1997). Designing and adapting materials to encourage learner autonomy. In P. Benson, \& P. Voller (Eds.), Autonomy and independence in language learning (pp. 192-203). London: Longman.

Nunan, D. (1999). Second language teaching and learning. Boston: Heinle \& Heinle.

Pinkman, K. (2005). Using blogs in the foreign language classroom: Encouraging learner independence. The JALT CALL Journal, 1(1), 2-24.

Reinders, H., \& Lazaro, N. (2011). Beliefs, identity and motivation in implementing autonomy: The teachers' perspective. In G. Murray, X. Gao, \& T. Lamb (Eds.), Identity, motivation, and autonomy in language learning (pp. 125-142). Bristol: Multilingual Matters

Seeman, T., \& Tavares, C. (2000). Getting the learners involved in their own learning - how to get started. In D. Little, L. Dam, \& J. Timmer (Eds.), Focus on Learning Rather than Teaching: Why and How? Papers from the International Association of Teachers of English as a Foreign Language (IATEFL) Conference (Krakow, Poland, May 14-16, 1998) (pp. 59-70). Dublin: Centre for Language and Communication Studies.

Smith, R. C., \& Palfreyman, D. (Eds.). (2003). Learner autonomy across cultures: Language education perspectives. Basingstoke: Palgrave Macmillan.

Smith, R. C. (2000). Starting with ourselves: Teacher-learner autonomy in language learning. In B. Sinclair, et al. (Eds.), Learner autonomy, teacher autonomy: Future directions (pp. 89-99). London: Longman.

Thanasoulas, D. (2000). What is learner autonomy and how can it be fostered? Internet TESL Journal, 6, 1-11.

Tudor, I. (1993). Teacher roles in the learner-centered classroom. ELT Journal, 47(1), 23-24. http://dx.doi.org/10.1093/elt/47.1.22

Voller, P. (1997). Does the teacher have a role in autonomous learning? In P. Benson, \& P. Voller (Eds.), Autonomy and Independence in Language Learning (pp. 98-113). London: Longman.

Warschauer, M., \& Healey, D. (1998). Computers and language learning: An overview. Language Teaching, 31(2), 57-71.

Warschauer, M., \& Whittaker, P. F. (1997). The internet for English teaching: Guidelines for teachers. Originally published in the TESL Reporter, 30(1), 27-33. http://dx.doi.org/10.1017/S0261444800012970

White, K., \& Weight, B. (2000). The online teaching guide: a handbook of attitudes, strategies and techniques for the virtual classroom. Needham Heights: Allyn \& Bacon.

Yoshiyuki, N. (2011). Teachers' readiness for promoting learner autonomy: A study of Japanese EFL high school teachers. Teaching and Teacher Education, 27(5), 900-910. http://dx.doi.org/10.1016/j.tate.2011.03.001 


\section{Appendix}

Practices and Prospects of Learner Autonomy: Teachers' Perceptions

Section 1: Learner Autonomy - Current situation

\begin{tabular}{lllll}
\hline & Statements & All & Male & Female \\
\hline 1. & Students compare their result with the results of other students. & 3.63 & 3.57 & 3.70 \\
\hline 2. & Students are keen to perform excellent in the classroom. & 3.58 & 3.30 & 3.87 \\
\hline 3. & $\begin{array}{l}\text { Students try to create a link with the learned concepts when they study a } \\
\text { new grammar rule. }\end{array}$ & 3.50 & 3.67 & 3.33 \\
\hline 4. & Students motivate themselves in learning English. & 3.40 & 3.30 & 3.50 \\
\hline 5. & Students can comment on selection of the study material. & 3.10 & 3.10 & 3.10 \\
\hline 6. & $\begin{array}{l}\text { In the beginning of the academic session, students identify their own } \\
\text { strengths and weaknesses. }\end{array}$ & 3.05 & 2.77 & 3.33 \\
\hline 7. & Students evaluate their progress in learning English during the session. & 3.00 & 3.00 & 3.00 \\
\hline 8. & Students share their learning goals with the teachers. & 2.97 & 2.73 & 3.20 \\
\hline 9. & Students set up their own learning goals. & 2.87 & 2.63 & 3.10 \\
\hline 10. & $\begin{array}{l}\text { Students discover language concepts on their own rather than waiting } \\
\text { for the teacher. }\end{array}$ & 2.75 & 2.63 & 2.87 \\
\hline
\end{tabular}

Section 2: Teaching Strategies

\begin{tabular}{lllll}
\hline & Statements & All & Male & Female \\
\hline 11. & Communicative skills are taught from the very beginning. & 4.37 & 4.07 & 4.67 \\
\hline 12. & Group discussion creates interest in English language learners. & 4.30 & 3.97 & 4.63 \\
\hline 13. & $\begin{array}{l}\text { I prefer learner-centered plus teacher's facilitation pattern in my } \\
\text { teaching. }\end{array}$ & 4.27 & 4.37 & 4.17 \\
\hline 14. & $\begin{array}{l}\text { The best strategy to encourage creativity among students in language } \\
\text { use is to assign home-based language tasks and projects to the students. }\end{array}$ & 3.78 & 3.57 & 4.00 \\
\hline 15. & English study skills mainly focus on the communication skills. & 3.75 & 3.70 & 3.80 \\
\hline 16. & $\begin{array}{l}\text { Only partial learners' autonomy is possible and the teacher should } \\
\text { decide what the learners do independently. }\end{array}$ & 3.70 & 3.73 & 3.67 \\
\hline 17. & $\begin{array}{l}\text { All decisions are made on the basis of teacher learner agreement and } \\
\text { negotiations. }\end{array}$ & 3.70 & 3.60 & 3.80 \\
\hline 18. & Students' poor responsibility is the main problem in English teaching. & 3.65 & 3.47 & 3.83 \\
\hline 19. & Poor learner's quality is the main problem in English teaching. & 3.62 & 3.57 & 3.67 \\
\hline 20. & Poor teaching facilities are the main problem in English teaching. & 3.50 & 3.23 & 3.77 \\
\hline
\end{tabular}

Section 3: Learner Autonomy - Futuristic

\begin{tabular}{|c|c|c|c|c|}
\hline & Statements & All & Male & Female \\
\hline 21. & $\begin{array}{l}\text { I think continuous professional development is important to improve } \\
\text { teaching learning process. }\end{array}$ & 4.60 & 4.70 & 4.50 \\
\hline 22. & $\begin{array}{l}\text { Reflecting with the students on the teaching/learning process helps me } \\
\text { identify some of their problems and find ways of solving them. }\end{array}$ & 4.37 & 4.30 & 4.43 \\
\hline 23. & $\begin{array}{l}\text { Focusing on learner training makes it possible for me to observe } \\
\text { improvement in the students' attitudes and communicative } \\
\text { competence. }\end{array}$ & 4.15 & 4.07 & 4.23 \\
\hline 24. & $\begin{array}{llll}\text { Providing learner training strategies prepares the teachers to } \\
\text { implement future action research projects. }\end{array}$ & 4.08 & 3.77 & 4.40 \\
\hline 25. & $\begin{array}{l}\text { Providing learner training contributes to the development of autonomy } \\
\text { as a teacher. }\end{array}$ & 4.05 & 3.87 & 4.23 \\
\hline 26. & $\begin{array}{l}\text { To be able to implement a learner-centered pedagogy and develop my } \\
\text { students' learning competencies, I need to improve my theoretical } \\
\text { knowledge in this field. }\end{array}$ & 3.82 & 3.47 & 4.17 \\
\hline 27. & $\begin{array}{l}\text { Learner training component is included in the teacher development } \\
\text { programs. }\end{array}$ & 3.98 & 3.87 & 4.10 \\
\hline 28. & $\begin{array}{l}\text { Learner training component fosters reflective attitude towards my } \\
\text { practice. }\end{array}$ & 3.82 & 3.70 & 3.93 \\
\hline 29. & $\begin{array}{l}\text { Learners should be as autonomous as possible, and teachers should } \\
\text { ensure this autonomy. }\end{array}$ & 3.72 & 3.37 & 4.07 \\
\hline 30. & I receive all necessary theoretical support from the university. & 3.35 & 3.07 & 3.63 \\
\hline
\end{tabular}

